\title{
The Performance Indicators for The State Health-related Expenditures: Lessons from OECD
}

\author{
Jakub Haas - Eva Gajdošová*
}

\begin{abstract}
:
The paper deals with the weakness of the Czech public finance - the lack of performance information. The budgeting in the Czech Republic still relies on the incremental method and omits using of performance indicators. On the contrary, most of the OECD member countries has adopted some type of performance budgeting. The paper focuses on the healthcare expenditures of the Czech state budget, analyses long-term experience with performance budgeting in the U.S.A., Australia and New Zealand. It also identifies opportunities and suggests the specific quantitative performance indicators for suitable programmes and organisations of the Ministry of Health.
\end{abstract}

Key words: Healthcare; Budgeting; Performance indicators.

JEL classification: H61, I18.

\section{Introduction}

Most of the OECD member countries adopted performance budgeting schemes several years ago. On the contrary, the state budget processes of the Czech Republic are based on the incremental method. Although some discussions and attempts to change it appeared, no systematic performance indicators are presently implemented to the public finance management. However, this situation only emphasizes the opportunity to learn from already tried international know-how.

The main objective of this study is to indicate opportunities of performance budgeting in healthcare expenditures of the Czech state budget. It is necessary to stress,that it covers the marginal part of health-related expenditures because general government amounts only to circa $3 \%$ of public expenditures on health; most of the public expenditures are made by health insurance funds (HIFs). The reason for selecting the state budget expenditures is that given institutional and legal obstacles surrounding the governance of HIFs the state budget might be more feasible part of the health-related expenditures for transformation into the performance budgeting framework.

\footnotetext{
Jakub Haas; Ministry of Finance of the Czech Republic, Public Budgets Section, Healthcare and Public Health Insurance Unit, Letenská 15, 11810 Prague 1, Czech Republic $<$ Jakub.Haas@mfcr.cz>.

Eva Gajdošová; University of Economics, Prague, Faculty of Finance and Accounting, Department of Public Finance, W. Churchill Sq. 4, 13067 Prague 3, Czech Republic, <xgaje00@vse.cz>.

The article is processed as an output of a research project Public finance in the Czech Republic and the $E U$ registered by IGA VŠE under the registration number F1/1/2016.
} 
Haas, J. - Gajdošová, E.: The Performance Indicators for The State Health-related Expenditures: Lessons from OECD.

This paper is based on previous research published by authors (Haas, Gajdošová, 2015), which is extended by additional analysis in all chapters. Especially the theoretical part was replenished by new arguments and the fourth chapter includes modified suggestion of the set of the quantitative indicators.

The first part of the paper is dedicated to the general explanation of performance budgeting principles. It introduces elementary types of budgeting based on performance and mechanisms which are important for adequate functioning of the system and discusses pros and cons of the performance budgeting. The second part contains an overview of the Ministry of Health of the Czech Republic recent expenditures. It shows the main spending categories and priorities.

The third chapter shows comparison of healthcare performance budgeting in selected OECD member states. This part offers detailed performance indicators that serve as the benchmark for assessing whether the political priorities were fulfilled or not. For this purpose, documents from Australia, New Zealand and the United States of America were utilized as these countries are usually considered to have the one of the most developed performance-oriented budgeting system.

The fourth part confronts performance indicators from OECD member countries mentioned above with the contemporary set of data used for healthcare budgeting in the Czech Republic. Definitions of obstacles and disadvantages as well as potential risks driven mainly from the international differences are also covered.

The conclusion, which draws on lessons learned in previous chapters, forms a final part of the paper. The conclusion should be viewed as the recommendations to the Czech Ministry of Health for its top-down approach to budgeting. The conclusions could be also helpful for the Ministry of Finance for the purpose of formulation and evaluation of the general budgetary policy.

\section{The Performance Budgeting: The Principles, Vindication and Criticism}

According to OECD "...there is no single agreed standard definition on performance budgeting. A variety of terms and definitions are incorporated under the label...These terms are all concerned with introducing performance information into budget processes.." (OECD, 2007 p. 20). Other source defines performance budgeting as a type of budgeting that "aims to improve the effectiveness and efficiency of public expenditure by linking the funding of public sector organizations to the results they deliver. It uses systematic performance information ... to make this link" (OECD, 2007 p. 12). Performance budgeting is not used only on the national level, but also on the regional and municipal level (Young, 2003).

It is necessary to note that the evolution of performance budgeting does not represent only modern trend of several years but, on the contrary, the result of long-term attempts and discussion dated back to the middle of the $20^{\text {th }}$ century. 
We can differentiate among two basic strategies, gradual adoption and "big bang" approach. The second conceptual dichotomy lies in the difference between topdown and bottom-up approaches. The former entrusts the main role to the hands of central government agency. In the case of the latter "the individual agencies are the key actors..., their participation can be voluntary and they have freedom to develop their own methods..." (Robinson, 2011 p. 33).

The third possible typology is constructed with respect to the comprehensiveness of the performance budgeting and differentiate between partial and comprehensive coverage of the public finance. The fourth classification recognizes three models according the relation between performance and funding and the main purpose in the budget process.

\section{Tab. 1: Types of performance budgeting}

\begin{tabular}{llll}
\hline Type & $\begin{array}{l}\text { Linkage between } \\
\text { performance and } \\
\text { funding }\end{array}$ & $\begin{array}{l}\text { Planned or actual } \\
\text { performance }\end{array}$ & $\begin{array}{l}\text { Main purpose in the } \\
\text { budget process }\end{array}$ \\
\hline Presentational & No link & $\begin{array}{l}\text { Performance targets } \\
\text { and/or performance } \\
\text { results }\end{array}$ & Accountability \\
$\begin{array}{l}\text { Performance- } \\
\text { informed budgeting }\end{array}$ & Indirect & $\begin{array}{l}\text { Performance targets } \\
\text { and/or performance } \\
\text { results }\end{array}$ & $\begin{array}{l}\text { Planning and/or } \\
\text { accountability }\end{array}$ \\
$\begin{array}{l}\text { Direct performance } \\
\text { budgeting }\end{array}$ & Tight & Performance results & $\begin{array}{l}\text { Resource allocation } \\
\text { and/or } \\
\text { accountability }\end{array}$ \\
\hline
\end{tabular}

Source: OECD, 2007, p. 21.

The crucial element of the performance budgeting is the right definition of plausible targets. Wrong definition can lead to undesirable effects. The performance targets should similarly to private sector meet "SMART criteria" (Doran, 1981, p. 35-36).

For designing good performance measurement indicators, what is an aim of this paper, six principles are highlighted and used in abbreviation F.A.B.R.I.C. Clear "Focus" means that indicators are connected with the core activities of a public organization. Information has to be "Appropriate" and useful for the key stakeholders. Then it is important to "Balance" the system in order to cover all significant activities. What is more, only "Robust" system can survive organizational or individual changes, if it is fully "Integrated" into the planning and processes of a public organization. Finally, obtaining performance information has to be "Cost-effective" (Pidd, 2012, p. $46-48$ ).

The long period of application of the performance budgeting in many countries has established base both for the vindication and the criticism. These two aspects 
Haas, J. - Gajdošová, E.: The Performance Indicators for The State Health-related Expenditures: Lessons from OECD.

mirror in countless literature upon this theme. In order to catch the most important features, the following discussion focuses on the most relevant advantages and disadvantages of the performance measurement.

The general advantage can be defined as following: "The use of performance information in budgetary decision making can contribute to budgetary goals of improving productive efficiency, allocative efficiency, and even aggregate fiscal discipline." (OECD, 2007, p. 11 - 12).

The partial advantages usually enumerated by the proponents of the performance budgeting are following:

- Improvement of expenditure prioritization (Robinson, Brumby, 2005, p. 13).

- Contribution to higher level of transparency (The Open Budget Survey 2015).

- Provision for better planning of expenditures (OECD, 2007, p. 11).

- Signalling device for information what programme is working and what is not (Ibid).

- "Encouraging line ministries to spend more efficiently and effectively by making them aware that their performance will influence their level of funding and by reducing or streamlining the controls that impede good performance" (Robinson, Last, 2009, p. 3).

The criticism is summed up to five points by OECD (OECD, 2015, p. 62 - 63):

- Performance is very hard to measure and to distinguishing the effect of the public funded activity from other factors.

- Single measurement for different outcomes and results is not possible, thus the comparison of different public funded activities has to be arbitrary.

- "Different activities may serve different people with different utilities and any

- interpersonal utility metric may be questioned." (p. 62)

- Politicians and officers may evaluate different programmes differently, so their preferences must prevail. Thus it might not lead to more effective spending of public finance than the incrementalism.

- Performance measure might not indicate the appropriate funding. The performance indicator can be interpreted in many ways.

Authors connected to International Monetary Fund also added another problematic feature of the performance-based budgeting. Generally, it can "crowd out the ethical/altruistic motivations which are felt by some to be crucial to good public sector performance." (Robinson, Brumby, 2005, p. 16). What is more, performance measures often regard quantity of outputs or outcomes, but they hardly capture qualitative characteristics. It can lead to "adverse behavioural distortions ... and erosion of quality of outcomes" (p. 16). Another difficult problem that has to be solved is the reward motivation of public officials and organisations to perform better. 
Other authors, such as Schick, differentiate between two basic approaches to the performance budgeting regarding the purpose - an analytic tool or a decision rule. The first one is consider to be a good instrument for the sound budgeting. The second one brings more problems than benefits because:

- It requires more robust cost accounting system. Data have to be attributed to discrete units of output or results, marginal, variable and fixed costs. But these accounting system is lacking in many countries, thus "government cannot allocate costs so as to connect incremental resources to the result" (p. 123).

- "Analysts and managers often engage in heated and protracted argument over the definition of outputs and outcomes, leaving insufficient opportunity to apply the data in the budget practices." (p. 123).

- "When it appropriates money, the government usually acquires the entire output of each spending unit for a fixed sum...the amount spent by the government does not vary if fewer or more outputs are produced." (p. 126).

According to Schick, the reforms that involve implementation of the performance budgeting should not go far than using performance indicators as an analytic tool and should respect existing organisational framework of funding. Otherwise, they are very likely to be unsuccessful.

\section{Situation in the Czech Republic}

Open Budget Survey 2015 pointed out the chronic problem of the Czech State budget documentation - the lack of information on performance. There are only financial indicators available and the public often cannot see the effect of the public expenditures. International Budget Partnership recommends following: "Increase the comprehensiveness of the Executive's Budget Proposal by presenting more information on policy narratives and performance information" and "Increase the comprehensiveness of the Year-End Report by presenting more information on .... and on planned versus actual performance." (The Open Budget Survey 2015). These recommendations can be applied for the budgeting the expenditures of the Ministry of Health $(\mathrm{MoH})$.

According to the 2014 Annual Report the expenditures of the MoH totalled up to 7,2 billion CZK. The current expenditures stand for the majority of the total, 5.7 billion CZK (79 \%). All these expenditures can be divided into many categories. Czech budget classification adopted a concept of "Specific Obligatory Indicators" that are laid down for every ministry or agency encompassed in the state budget. These financial indicators are not allowed to be adjusted without permission of the Ministry of Finance (MoF) or the Budget Committee of the House of Deputies. 
Haas, J. - Gajdošová, E.: The Performance Indicators for The State Health-related Expenditures: Lessons from OECD.

Tab. 2: Specific Obligatory Indicators of the Ministry of Healthcare in 2014

\begin{tabular}{lll}
\hline Indicator & mil. CZK & Share \\
\hline State administration & 2054 & $28,6 \%$ \\
Research \& Development & 1229 & $17,1 \%$ \\
Hospital care & 1172 & $16,3 \%$ \\
Particular healthcare facilities and services & 974 & $13,6 \%$ \\
Health programmes & 1475 & $20,5 \%$ \\
Other activities & 280 & $3,9 \%$ \\
Total & $\mathbf{7 1 8 4}$ & $\mathbf{1 0 0 , 0 \%}$ \\
\hline
\end{tabular}

Source: Ministry of Health of the Czech Republic, 2014.

"State administration" contains all expenditures related to the existence and operations of MoH (salaries, payroll taxes, IT services, , facility management etc.) and other agencies under $\mathrm{MoH}$ with state administration function (State Institute for Drug Control, Regional Hygienic Offices etc.). „Research \& Development” expenditures are mainly transfers to state-owned hospitals and public universities for both institutional and targeted support of R\&D. Indicator "Hospital care" covers all current and capital transfers to state-owned hospitals, non-state or specialized organizations which provide healthcare.

There are agencies encompassed in the $\mathrm{MoH}$ budget chapter that do not perform state administration such as the Institute of Health Information and Statistics. Their funding forms roughly one half of the indicator "Particular healthcare facilities and services". The rest is used for funding of the air rescue service ensured mainly by private providers. Indicator "Health programmes" consists of a wide range of subsidy programmes. They aim to improve public health, support healthy lifestyle and deals with AIDS prevention, physical disability, etc. "Other activities" include financing of the international cooperation or specialized education of health professionals..

The other type of obligatory indicators is "Cross-sectional Obligatory Indicators", also financial and not performance-related, which consists of rather common indicators for all ministries and agencies such as wages and certain specific programmes: 


\section{Tab. 3: Cross-sectional Obligatory Indicators of the Ministry of Healthcare} in 2014

\begin{tabular}{lll}
\hline Indicator & mil. CZK & Share \\
\hline Anti-drug programme & 15 & $0,21 \%$ \\
Vaccination & 9 & $0,13 \%$ \\
Social prevention & 0,4 & $0,01 \%$ \\
Readiness for crisis situation & 8 & $0,11 \%$ \\
Programme financing & 1460 & $20,32 \%$ \\
Anti-drug programme & 15 & $0,21 \%$ \\
\hline
\end{tabular}

Source: Ministry of Health of the Czech Republic, 2014.

The MoH's Annual Review is informative only in terms of financial data. The evaluation of the expenditures is based only on year-to-year comparison and on the compliance of the financial plan. Expenditure prioritization could be regarded as a "black box" because neither formal rules, nor other consistent principles are used. The decisions are mainly based on political agenda and influences of various stakeholders. This fact has already been criticized by several scholars (e.g. Ochrana, 2003). There is a lack of information in the budget documentation on the objectives of $\mathrm{MoH}$ as well as, with some rare exceptions, on the qualitative indicators. Therefore, no one knows how $\mathrm{MoH}$ measures the progress towards the stated objectives or why it allocates certain amount of money on each particular programme.

The both budget legislation and practice have implemented "programme financing" which is an attempt to come close to long-term budgeting with quantitative targets. But it is used mainly in case of investment expenditures.. The "programme financing" is held under the special regime apart from other expenditures. Under this regime for each project is defined the set of financial and output target indicators that have to be achieved but using of performance indicators is very scarce.

As an example to illustrate the shortcomings of current approach the programme called "Supporting the development and renewal of material and technical base of the university hospitals" has been chosen. One of the projects is named "International Clinical Research Centre Brno" As it is shown in Table 4, used indicators are far away from principles of performance budgeting. They are not connected with the objective of improving health status of population, there is no linkage between finance and performance and they covers only unclear instruments with no respect to meet public needs. 
Haas, J. - Gajdošová, E.: The Performance Indicators for The State Health-related Expenditures: Lessons from OECD.

\section{Tab. 4: Examples of quantitative non-financial indicators of programme financing}

\begin{tabular}{|c|c|c|c|c|c|c|c|c|c|c|}
\hline & \multirow{3}{*}{$\begin{array}{c}\text { State } \\
31.12 . \\
2012\end{array}$} & \multicolumn{3}{|c|}{$\begin{array}{l}\text { Development of the parameter at the } \\
\text { time of realization }\end{array}$} & \multicolumn{6}{|c|}{ Average costs of parameter at the time of realization } \\
\hline & & \multirow{2}{*}{$\begin{array}{c}\text { Property } \\
\text { acquisition }\end{array}$} & \multirow{2}{*}{$\begin{array}{l}\text { Property } \\
\text { appreciation }\end{array}$} & \multirow{2}{*}{$\begin{array}{c}\text { Rental } \\
\text { property }\end{array}$} & \multicolumn{2}{|c|}{$\begin{array}{c}\text { In } 1000 \text { CZK on unit of } \\
\text { measure }\end{array}$} & \multicolumn{4}{|c|}{ In $1000 \mathrm{CZK}$ per year } \\
\hline & & & & & $\begin{array}{c}\text { Property } \\
\text { acquisition }\end{array}$ & $\begin{array}{l}\text { Property } \\
\text { Appreciation }\end{array}$ & $\begin{array}{c}\text { Repair } \\
\text { and maint. }\end{array}$ & $\begin{array}{c}\text { Material } \\
\text { and Energy }\end{array}$ & $\begin{array}{c}\text { Rental } \\
\text { property }\end{array}$ & Services \\
\hline Indicator & \multicolumn{10}{|c|}{ Floor area of offices and workrooms (unit of measure $-\mathrm{m} 2$ ) } \\
\hline Parameter value & 148521 & 4742 & 51741 & 8592 & 29 & 17 & & 1 & & 2 \\
\hline Obligation & MIN & MIN & MAX & MAX & MAX & MAX & & MAX & & MAX \\
\hline Indicator & \multicolumn{10}{|c|}{ Automobiles - lower class (unit of measure - pieces) } \\
\hline Parameter value & 62 & 18 & 4 & & 344 & 3 & 17 & 57 & & 7 \\
\hline Obligation & MIN & MIN & MAX & & MAX & MAX & MAX & MAX & & MAX \\
\hline
\end{tabular}

Source: Government of the Czech Republic, 2006.

\section{The Practice in the OECD Countries}

The public budget reforms, that took part in the most OECD countries at the end of 20th century, have implemented performance indicators to the budget documentation and process. The main features of the performance indicators for healthcare of three OECD members: Australia, New Zealand and the United States of America have been examined.

\subsection{Australia}

The agenda of the Department of Health is divided into outcomes which are presented by one or more programmes contributing to the certain outcome. There are definitions of outcome strategies, programme objectives, Qualitative Key Performance Indicators (KPI - consist of Qualitative Indicators and Budget Year Reference Point or Target) and Quantitative Deliverables (D) along with financial information on expenses.

We will take Outcome 3 - Access to Medical and Dental Services - as an example. This Outcome covers six programmes and the Australian Government plans to allocate 21.6 billion AUD there in the budget year of 2014/2015. One of the programmes deals with the problem of the radiation oncology services: "The Australian Government aims to improve access to high quality radiation oncology services by funding approved equipment, quality programmes and initiatives to support the radiotherapy workforce." (Australian Government Department of Health, 2014, p. 87).

Quantitative indicator is defined as the number of sites delivering radiation of oncology. The numbers are not only laid down for the actual and previous year but even for three forward years. The taxpayers and other stakeholders can learn from the budget documentation that the Australian Government wants to improve the 
access to the radiation oncology services by raising the number of sites from 69 in the budget year 2014-5 to 76 in 2017-8.

However, Qualitative Key Performance Indicators for sub-programme are not concretized. The first only states that "Diagnostic radiology services are effective and safe". The second and final one promises that the system of accreditation will be reviewed "to ensure that Medicare funding is directed to diagnostic imaging services that are safe, effective and responsive to the needs of health care consumers." (Australian Government Department of Health 2014, p.89).

The table below lists the qualitative indicators for the programs clustered under the Outcome 1 - Population health with more concretized KPIs. Objective is a reduction in the incidence of preventable mortality and morbidity.

Tab. 5: Quantitative indicators for the programs of Outcome 1

\begin{tabular}{|c|c|c|c|c|c|c|}
\hline \multirow[t]{2}{*}{ Programs } & \multirow{2}{*}{ Quantitative Indicator } & \multirow{2}{*}{$\begin{array}{l}2013-14 \\
\text { Revised } \\
\text { Budget }\end{array}$} & $\begin{array}{l}\text { 2014-15 } \\
\text { Budget }\end{array}$ & $\begin{array}{l}\text { 2015-16 } \\
\text { Forward }\end{array}$ & $\begin{array}{l}\text { 2016-17 } \\
\text { Forward }\end{array}$ & $\begin{array}{l}2017-18 \\
\text { Forward }\end{array}$ \\
\hline & & & Target & Year 1 & Year 2 & Year 3 \\
\hline \multirow{5}{*}{$\begin{array}{l}\text { Public } \\
\text { Health, } \\
\text { Chronic } \\
\text { Disease } \\
\text { and } \\
\text { Palliative } \\
\text { Care }\end{array}$} & $\begin{array}{l}\text { D - Number of breast care nurses } \\
\text { employed through the McGrath } \\
\text { Foundation }\end{array}$ & 53 & 57 & 57 & 57 & 57 \\
\hline & $\begin{array}{l}\text { KPI - Percentage of people invited } \\
\text { to take part in the National Bowel } \\
\text { Cancer Screening Program who } \\
\text { participated }\end{array}$ & $41 \%$ & $41 \%$ & $41 \%$ & $41 \%$ & $41 \%$ \\
\hline & $\begin{array}{l}\text { KPI - Percentage of women 50-69 } \\
\text { years of age participating in } \\
\text { BreastScreen Australia }\end{array}$ & $55,2 \%$ & $55,2 \%$ & $55,2 \%$ & $55,2 \%$ & $55,2 \%$ \\
\hline & $\begin{array}{l}\text { KPI - Percentage of women } 70-74 \\
\text { years of age participating in } \\
\text { BreastScreen Australia }\end{array}$ & $34,0 \%$ & $51,0 \%$ & $53,0 \%$ & $55,2 \%$ & $55,2 \%$ \\
\hline & $\begin{array}{l}\text { KPI - Percentage of women in the } \\
\text { target age group participating in } \\
\text { the National Cervical Screening } \\
\text { Programme }\end{array}$ & $57 \%$ & $57 \%$ & $57 \%$ & $57 \%$ & $57 \%$ \\
\hline
\end{tabular}


Haas, J. - Gajdošová, E.: The Performance Indicators for The State Health-related Expenditures: Lessons from OECD.

\begin{tabular}{|c|c|c|c|c|c|c|}
\hline \multirow[t]{2}{*}{ Programs } & \multirow[t]{2}{*}{ Quantitative Indicator } & \multirow{2}{*}{$\begin{array}{l}2013-14 \\
\text { Revised } \\
\text { Budget }\end{array}$} & $\begin{array}{l}2014- \\
15 \\
\text { Budget }\end{array}$ & $\begin{array}{l}2015-16 \\
\text { Forward }\end{array}$ & $\begin{array}{l}2016-17 \\
\text { Forward }\end{array}$ & $\begin{array}{l}\text { 2017-18 } \\
\text { Forward }\end{array}$ \\
\hline & & & Target & Year 1 & Year 2 & Year 3 \\
\hline \multirow{2}{*}{$\begin{array}{l}\text { Drug } \\
\text { Strategy }\end{array}$} & $\begin{array}{l}\text { KPI - Percentage of population } \\
14 \text { years of age and older } \\
\text { recently (in the last } 12 \text { months) } \\
\text { using an illicit drug }\end{array}$ & $<13,4 \%$ & $<13,4 \%$ & $<13,4 \%$ & $<13,4 \%$ & $<13,4 \%$ \\
\hline & $\begin{array}{l}\text { KPI - Percentage of population } \\
18 \text { years of age and over who are } \\
\text { daily smokers }\end{array}$ & $15,2 \%$ & $13,9 \%$ & $12,6 \%$ & $11,3 \%$ & $10,0 \%$ \\
\hline \multirow{4}{*}{$\begin{array}{l}\text { Immuni- } \\
\text { sation }\end{array}$} & $\begin{array}{l}\text { D - Number of completed } \\
\text { tenders under the National } \\
\text { Partnership Agreement on } \\
\text { Essential Vaccines (Essential } \\
\text { Vaccines Procurement Strategy) }\end{array}$ & 2 & 2 & 2 & 2 & 1 \\
\hline & $\begin{array}{l}\text { KPI - Increase the immunisation } \\
\text { coverage rates among children } \\
12-15 \text { months of age }\end{array}$ & $91,8 \%$ & $92,0 \%$ & $92,3 \%$ & $92,5 \%$ & $92,8 \%$ \\
\hline & $\begin{array}{l}\text { KPI - Increase the immunisation } \\
\text { coverage rates among children } \\
24-27 \text { months of age }\end{array}$ & $92,7 \%$ & $92,9 \%$ & $93,2 \%$ & $93,4 \%$ & $93,7 \%$ \\
\hline & $\begin{array}{l}\text { KPI - Increase the immunisation } \\
\text { coverage rates among children } \\
60-63 \text { months of age }\end{array}$ & $90,0 \%$ & $91,5 \%$ & $91,7 \%$ & $92,0 \%$ & $92,2 \%$ \\
\hline
\end{tabular}

Source: Australian Government Department of Health, 2014.

\subsection{New Zealand}

The Ministry of Health presented the Statement of Intent 2014 - 2018 to the House of Representatives and published it on its websites. It defines seven health targets for the fiscal year 2014/2015. These form set of national performance measures specifically designed to improve the performance of key health services of particular concern to patients. 
European Financial and Accounting Journal, 2016, vol.11, no. 1, pp. 05-22.

\section{Tab. 6: The health targets and qualitative measures for FY 2014/2015}

\begin{tabular}{ll}
\hline Health target & Quantitative measures \\
\hline $\begin{array}{l}\text { Shorter stays in } \\
\text { emergency } \\
\text { departments }\end{array}$ & $\begin{array}{l}\text { 95\% of patients will be admitted, discharged, or transferred from an } \\
\text { Emergency Department within 6 hours. }\end{array}$ \\
$\begin{array}{l}\text { Improved access to } \\
\text { elective surgery }\end{array}$ & $\begin{array}{l}\text { The volume of elective surgery will be increased by at least 4000 discharges } \\
\text { per year. }\end{array}$ \\
$\begin{array}{l}\text { Shorter waits for } \\
\text { cancer treatment }\end{array}$ & $\begin{array}{l}\text { All patients, ready for treatment, wait less than 4 weeks for radiotherapy or } \\
\text { chemotherapy. }\end{array}$ \\
$\begin{array}{l}\text { Faster cancer } \\
\text { treatment }\end{array}$ & $\begin{array}{l}\text { 85\% of patients will receive their first cancer treatment within 62 days of } \\
\text { being referred urgently with a high suspicion of cancer by July 2016. }\end{array}$ \\
$\begin{array}{l}\text { Increased } \\
\text { immunisation }\end{array}$ & $\begin{array}{l}90 \% \text { of 8-month-olds will have their primary course of immunisation on } \\
\text { time by July 2014 and 95\% by December 2014 }\end{array}$ \\
$\begin{array}{l}\text { 95\% of hospitalised smokers are seen by a health practitioner in public } \\
\text { hospitals and 90\% of enrolled patients who smoke and are seen by a health } \\
\text { practitioner in general practice are offered brief advice and support to quit } \\
\text { smoking. }\end{array}$ \\
$\begin{array}{l}90 \% \text { of the eligible population will have had their cardiovascular risk } \\
\text { smokers to quit }\end{array}$ \\
$\begin{array}{l}\text { More heart and } \\
\text { diabetes checks }\end{array}$
\end{tabular}

Source: Ministry of Health, New Zealand, 2014.

Apart from Australia, the New Zealand Government approach to performance budgeting focuses on the relatively small number of targets. They do not cover all areas of healthcare expenditures but enable demonstration of the most important priorities of the federal government. The targets are defined clearly and easily understandable for the public.

\subsection{The United States of America}

The Department of Health and Human Services in its Annual Performance Report and Performance Plan (2010-2015) lists five Strategic Goals. Each of them contains several Objectives.. Report provides information on the progress toward achieving the goals and objectives described in the Strategic Plan and Annual Performance Plan.

The 2014-2018 Strategic Plan contains four Strategic Goals and 20 Objectives. For each of them set of quantitative targets is established along with the responsibility of lead agency for every target. The Department also lays down short-term Priority Goals only for one budget year. 
Haas, J. - Gajdošová, E.: The Performance Indicators for The State Health-related Expenditures: Lessons from OECD.

\section{Tab. 7: Quantitative performance indicators for the Priority Goals}

\begin{tabular}{ll}
\hline Priority Goal & Quantitative performance indicator \\
\hline $\begin{array}{l}\text { Improve health care through meaningful } \\
\text { use of health ICT }\end{array}$ & $\begin{array}{l}\text { Increase the number of providers who receive incentive } \\
\text { payments from the Medicare and Medicaid Electronic } \\
\text { adoption or demonstration of meaningful use of certified }\end{array}$ \\
& EHR technology to $425,000$. \\
& $\begin{array}{l}\text { Reduce the annual adult combustible tobacco } \\
\text { consumption from } 1,342 \text { to } 1,174 \text { cigarette equivalents } \\
\text { per capita, which will represent an approx. } 12 \% \text { decrease } \\
\text { from the } 2012 \text { baseline. }\end{array}$ \\
Reduce combustible & $\begin{array}{l}\text { Decrease the rate of Salmonella illness from } 2.6 \text { to } 1.9 \\
\text { cases per } 100,000 \text { inhabitants. }\end{array}$ \\
tobacco use & $\begin{array}{l}\text { Reduce the healthcare-associated infections by } \\
\text { demonstrating a } 10 \text { percent reduction in national hospital- } \\
\text { acquired catheter-associated urinary tract infections from } \\
\text { the current SIR of } 1.02 \text { to } 0.92 .\end{array}$ \\
Reduce foodborne illness & Human Serving
\end{tabular}

Source: U.S. Department of Health \& Human Services, 2014.

There is also the deadline settled for the achieving the quantitative target of each Priority Goal. Apart from the Priority Goals, the Strategic Goals cover usually 4-6year period. There is no obligation to cover the whole period therefore some Strategic Goals do not consist indicators for each year of the period. In Annual Performance Report the Department evaluates whether the quantitative targets were met or not.

Our example is the Goal 3 - Advance the Health, Safety and Well-being of the American People. This Goal consists of six Objectives marked from "A" to "F." We choose Objective D - Promote prevention and wellness across the lifespan with nine quantitative targets. Increase the percentage of Early Head Start Children completing all medical screenings to $91 \%$ by 2010, $92 \%$ by 2011 and $93 \%$ by 2012. For the year 2010 target was not met because the result was 84.9 $\%$. For the period of 2011-2012 target was not met neither but the results improved to $85,9 \%$. For the period of 2013-2015 the results data are not available. The brief list of other examples of the quantitative targets is shown in the Table 8: 
Tab. 8: Examples of quantitative targets in the USA

\begin{tabular}{lccccc}
\hline FY 2010 & FY 2011 & FY 2012 & FY 2013 & FY 2014 & FY 2015 \\
\hline Reduce the annual adult combustible tobacco consumption in the United States (cigarettes) \\
Target & $\begin{array}{l}1342 \text { per } \\
\text { capita }\end{array}$ & $\begin{array}{l}1259 \text { per } \\
\text { capita }\end{array}$ & $\begin{array}{l}1212 \text { per } \\
\text { capita }\end{array}$ & $\begin{array}{l}1174 \text { per } \\
\text { capita }\end{array}$ \\
\hline
\end{tabular}

The total number of tobacco compliance check inspections of retail establishments

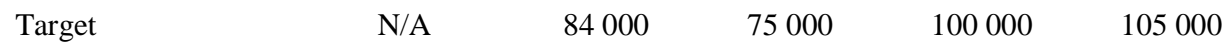

Reduce the proportion of adults (aged 18 and over) who are current cigarette smokers

$\begin{array}{llllll}\text { Target } & \text { Set Baseline } & 20,5 \% & 20 \% & 19 \% & 18 \%\end{array}$

Increase the number of calls answered by the suicide hotline

$\begin{array}{lllllll}\text { Target } & 555132 & 555132 & 555132 & 555132 & 765638 & 989994\end{array}$

Increase the percentage of adults with severe mental illness receiving homeless support services who report positive functioning at 6 month follow-up

$\begin{array}{lllllll}\text { Target } & 66 \% & 62,3 \% & 68,4 \% & 63,1 \% & 63,1 \% & 66,1 \%\end{array}$

Source: U.S. Department of Health \& Human Services, 2014.

\section{The Possibilities and Obstacles for the Czech Republic}

The introduction of performance information into the state budget process would bring certain risks. Most of them can arise from hurried time schedule. If the $\mathrm{MoH}$ had not enough time to prepare for implementing performance indicators it could lead to the undesirable outcomes. Because of this the gradual reform is more adequate in the Czech settings than the big bang one. It means adopting should get through all three stage of performance budgeting gradually with partial coverage:

1. To develop performance indicators and objectives in order to establish presentational model. The aim of this step is to introduce the performance indicators, to authenticate an availability of the data, sufficient and robust timeseries and to avoid incorrect interpretation of the data. This stage could take from two to three years.

2. This second step would assure that both ministries are able to use performance indicators in the budgeting process and they would develop indirect linkage between resources and performance indicators The risk would be eliminated by the preference of the political decision, if there was an uncertainty that decision based on the performance indicator would lead to desirable outcomes. The duration of this stage is estimated on two years in order to work out new processes. 
Haas, J. - Gajdošová, E.: The Performance Indicators for The State Health-related Expenditures: Lessons from OECD.

3. Direct performance budgeting model should be the ultimate step but only for carefully selected programmes and expenditure areas. All main risks were acceptably lowered in the previous stages.

Another risk can arise from personal changes in public administration, therefore our strategy respects existing organisational framework of funding. Nonetheless, present form of incremental budgeting is more vulnerable to this type of risk than the performance budgeting. This is caused mainly by clearly defined and published targets of the performance budgeting which is not secret know-how of certain officials that appears in the model of incremental budgeting.

Top-down approach is considered to be moreadequate for the Czech Republic than the opposite one. After quarter of century of post-communist state existence no successful attempt emerged from individual ministries. To enumerate the most important advantages of the top-down approach, it enables solid co-ordination, stronger pressure for implementation and more information at the centre to enhance decision-making.

The first line of adoption of performance-oriented budgeting leads from MoF to $\mathrm{MoH}$. The second one links the needs of 20 agencies under $\mathrm{MoH}$ with the resources available to the central agency. Along with the usual usage within $\mathrm{MoH}$, the elements of performance budgeting might be used in evaluation of the repeated budgetary over-requirements by MoF. Both institutions would evaluate whether planned goals of program were successfully met.

The most comprehensive indicators of healthcare measure effects directly on improving health status of citizens (i.e. life expectancy), but that there is no straightforward and uncomplicated causal relation.There are many other determinants which affect health status, this is the reason why we do not rely solely on outcome-based indicators. There must be a mix of output and outcome indicators (e.g. for the programme of investment transfers).

Table 9 shows possible quantitative indicators, the most of them are non-financial: 


\section{Tab. 9: Heading of the table Suggested quantitative indicators for the healthcare expenditures from the state budget}

\begin{tabular}{|c|c|c|}
\hline $\begin{array}{l}\text { Obligatory } \\
\text { Specific } \\
\text { Indicator }\end{array}$ & $\begin{array}{l}\text { Programme/ area/ } \\
\text { institution }\end{array}$ & Suggested performance indicator/ target \\
\hline \multirow[b]{2}{*}{$\begin{array}{l}\text { State } \\
\text { administration }\end{array}$} & $\begin{array}{l}\text { State Institute for Drug } \\
\text { Control }\end{array}$ & $\begin{array}{l}\text { Savings achieved thank to price revisions, access } \\
\text { to pharmaceuticals }\end{array}$ \\
\hline & $\begin{array}{l}\text { Regional Hygienic } \\
\text { Offices }\end{array}$ & $\begin{array}{l}\text { Reducing } \% \text { of swimming sites with } \\
\text { unacceptable water quality, number of } \\
\text { participants in and "Healthy school" projects, } \\
\text { number of on-site checks, \% coverage of checks }\end{array}$ \\
\hline $\begin{array}{l}\text { Research \& } \\
\text { Development } \\
\text { in healthcare }\end{array}$ & $\begin{array}{l}\text { Institutional support of } \\
\text { R\&D, Targeted } \\
\text { support of R\&D }\end{array}$ & $\begin{array}{l}\text { Number of patents, reducing case-mix adjusted } \\
\text { cost, number of patients benefited from R\&D }\end{array}$ \\
\hline Hospital care & $\begin{array}{l}\text { Investment transfers, } \\
\text { individual projects }\end{array}$ & $\begin{array}{l}\text { Access to medical services, number of patients } \\
\text { benefited from, effective coverage in regions }\end{array}$ \\
\hline \multirow{3}{*}{$\begin{array}{l}\text { Particular } \\
\text { healthcare } \\
\text { facilities and } \\
\text { services }\end{array}$} & $\begin{array}{l}\text { Regional emergency } \\
\text { service }\end{array}$ & Number of cases, waiting time \\
\hline & $\begin{array}{l}\text { National Medical } \\
\text { Library }\end{array}$ & $\begin{array}{l}\text { Number of book borrowings, access to digital } \\
\text { sources }\end{array}$ \\
\hline & Air rescue service & Number of flights, waiting time \\
\hline \multirow{5}{*}{$\begin{array}{l}\text { Health } \\
\text { programmes }\end{array}$} & $\begin{array}{l}\text { Equalization of } \\
\text { opportunities for } \\
\text { persons with } \\
\text { disabilities }\end{array}$ & $\begin{array}{l}\text { Number of persons with disabilities using } \\
\text { rehabilitation services, new volunteer centers }\end{array}$ \\
\hline & Care for children & Reducing $\%$ of obese children \\
\hline & Long term care & Reducing incidence of decubitus ulcers (\%) \\
\hline & Anti/drug policy & Reducing the proportion of cigarette smokers (\%) \\
\hline & AIDS prevention & Reducing HIV/AIDS incidence (\%) \\
\hline \multirow{2}{*}{ Other activities } & Medical education & $\begin{array}{l}\text { Number of successful participants, \% graduates } \\
\text { staying in the Czech Republic }\end{array}$ \\
\hline & $\begin{array}{l}\text { International } \\
\text { cooperation }\end{array}$ & Number of foreign students supported \\
\hline
\end{tabular}

Source: Authorial computation. 
Haas, J. - Gajdošová, E.: The Performance Indicators for The State Health-related Expenditures: Lessons from OECD.

All proposed indicators are designed in order to fulfil the FABRIC criteria. They are focused on core activities of the $\mathrm{MoH}$ and its agencies and can be integrated to the management process as well as to the budget process. The question, whether they are robust to withstand organizational changes, is narrowly connected to their acceptance of both politicians and experts. Most indicators are based on the longterm experience from OECD countries, therefore we assume high probability of their acceptance.

The suggested indicators should be understood as the examples, most suitable in an opinion of the authors of this paper, but not as the complete list of all possibilities. Therefore, indicators are not balanced in order to capture all activities of the $\mathrm{MoH}$ and its agencies. Most of suggested indicators are already measured and monitored by the $\mathrm{MoH}$, its agencies or health insurance funds but not used in the budget process. There would occur no substantial extra costs in case of implementation of these indicators.

The suggested indicators are specific enough to be attached to each Obligatory Specific Indicator and to be fulfilled by each organization under the $\mathrm{MoH}$ as the Table 9 shows. The measurability of each indicator requires robust statistics and ability of involved organisations to work with data. The experience from OECD countries proves that it is possible.

The questions, whether $\mathrm{MoH}$ would be able to achieve the targets and how realistic they should be, are not answered in this paper. This is not its objective for it does not specify numerical value of each target. It deserves autonomous discussion of the value that could be achievable and desirable. The discussion has to involve both politicians and experts. But suggested indicators provide suitable framework for this discussion.

The targets based on the suggested indicators should be time-bound. The shortest period could be one calendar year because the state budget is constructed on this period. The mid-term targets should cover three-year period according to contemporary three-year Expenditure Outlook approved by the Chamber of Deputies. The period of the long-term targets should depend on the duration of long-term strategies or programmes. E.g., the national strategy Health 2020 covers period of seven years. 


\section{Conclusions}

The majority of the health-related expenditures from the state budget in the Czech Republic is suitable for implementation of the performance budgeting. This conclusion is based on the analysis of the long-term experience from the three OECD member states. The performance indicators should apply especially to investment transfers to hospital, public health and prevention programmes and medical education. This study suggests adequate strategy for transition to performance budgeting: top-down implementation approach,, gradual process from presentational model and partial coverage for selected programmes into the direct linkage with financial resources. Proposed strategy respects existing organizational framework of funding. Transitional period could last five years to avoid undesirable results and eliminate variety of risks.

\section{References}

Australian Government department of Health, 2014. Australian Government 201415 Health Portfolio Budget Statements - Department Outcomes. Available from: <https://health.gov.au/internet/budget/publishing.nsf/Content/2014-2015_Health _PBS>. [24 March 2015].

Doran, G. T., 1981. There's a S.M.A.R.T. way to write management's goals and objectives. Management Review (AMA FORUM) 70 (11).

Government of the Czech Republic, 2006. Resolution of the Government of the Czech Republic dated July 12, 2006 no. 859 to implement projects for the ICRC Brno and to secure its financing, Praha.

Haas, J., Gajdošová, E., 2015. The Quantitative Performance Indicators and Targets for Financing Healthcare from the State Budget - Challenge for the Czech Republic. Theoretical and Practical Aspects of Public Finance, Prague.

Ministry of Health, New Zealand, 2014. Statement of Intent 2014 to 2018 Ministry of Health, Wellington.

Ministry of Healthcare of the Czech Republic (MoH), 2014. Annual Review 2014, Praha.

OECD, 2007. Performance Budgeting in OECD Countries. OECD Publishing, Paris.

OECD, 2015. Fiscal Sustainability of Health Systems: Bridging Health and Finance Perspectives. OECD Publishing, Paris.

Ochrana, F., 2003. Veřejná volba a řízení veřejných výdajů. Ekopress, Praha.

Pidd, M., 2012. Measuring the Performance of Public Services. Cambridge University Press, Cambridge. 
Haas, J. - Gajdošová, E.: The Performance Indicators for The State Health-related Expenditures: Lessons from OECD.

Robinson, M., 2011. Performance-based Budgeting, Manual, CLEAR Training material. Available from: <www.theclearinitiative.org/PDFs/CLEAR_PB _Manual.pdf>. [25 March 2015].

Robinson, M., Brumby, J., 2005. Does Performance Budgeting Work? IMF Working Paper, WP/05/210, Washington.

Robinson, M., Last D., 2009. A Basic Model of Performance-Based Budgeting IMF Technical Notes and Manuals. Fiscal Affair Department, Washington.

Schick, A., 2007. Performance Budgeting and Accrual Budgeting: Decision Rules or Analytic Tools. OECD Journal of Budgeting 2, 109-138.

The Open Budget Survey, 2015. Results by Country - Czech Republic. Available from: <http://internationalbudget.org/opening-budgets/open-budget-initiative /open-budget-survey/country-info/?country=cz>. [25 October 2015].

U.S. Department of Health \& Human Services, 2014. Annual Performance Report and Performance Plan - Fiscal year 2015, Washington.

Young, R. D., 2003. Performance-Based Budget Systems, Public Policy and Practice. USC Institute for Public Service and Policy Research, University of South Carolina. 